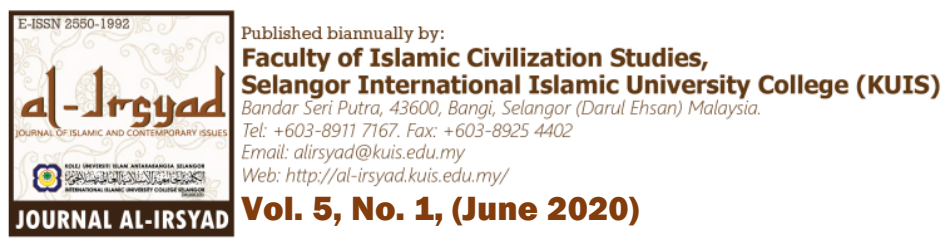

\title{
Risiko Gangguan Seksual di dalam Rumah kepada Remaja
}

\author{
[The Risk of Sexual Harassment in House to Teenagers]
}

\section{Norsaleha Mohd. Salleh', Kamal Azmi Abd. Rahman', Noor Hafizah Mohd. Haridi' ${ }^{1}$, Norbahiah Misran ${ }^{2}$, Zetty Nurzuliana Rashed ${ }^{3}$, \& Nabilah Huda Zaim ${ }^{1}$}

\author{
${ }^{1}$ Jabatan Dakwah dan Usuluddin, Fakulti Pengajian Peradaban Islam, Kolej Universiti Islam Antarabangsa \\ Selangor. \\ 2 Jabatan Kejuruteraan Elektrik, Elektronik \& Sistem, Fakulti Kejuruteraan \& Alam Bina, Universiti \\ Kebangsaan Malaysia, Selangor. \\ 3 Jabatan Asas Kemanusiaan dan Perkaedahan, Fakulti Pendidikan, Kolej Universiti Islam Antarabangsa \\ Selangor. \\ * Corresponding Author: Dr. Norsaleha Mohd. Salleh, Jabatan Dakwah dan Usuluddin, Fakulti Pengajian \\ Peradaban Islam, Kolej Universiti Islam Antarabangsa Selangor. E-mail: norsaleha@kuis.edu.my. Tel: (+60) \\ 193341494. ORCID iD: https://orcid.org/0000-0003-0338-3054
}

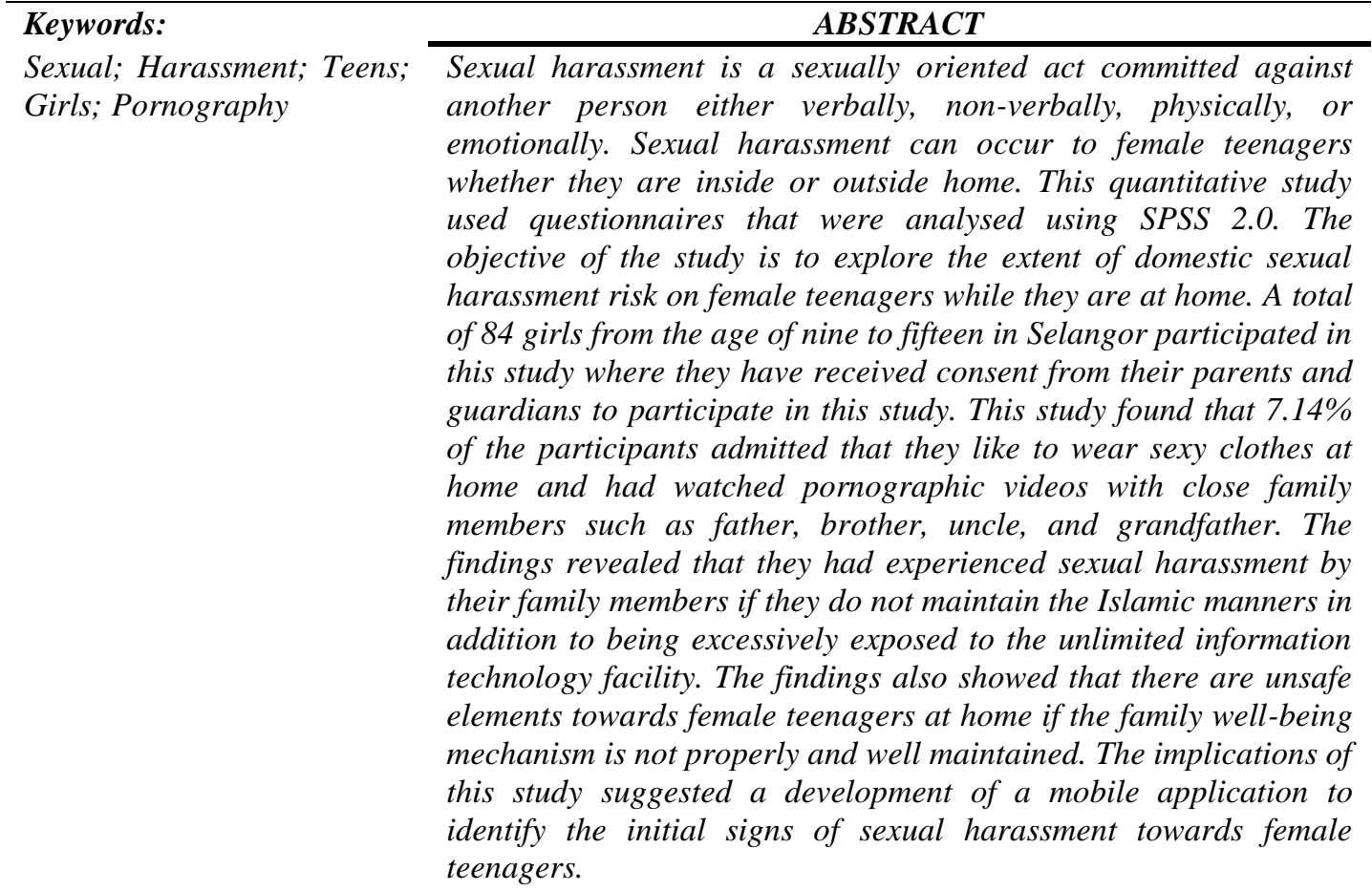

\section{Kata Kunci:}

Gangguan; Seksual; Remaja; Perempuan; Pornografi

\section{ABSTRAK}

Gangguan seksual merupakan perlakuan berbaur seks yang dilakukan terhadap individu lain sama ada berbentuk lisan, bukan lisan, fizikal atau emosi. Gangguan seksual boleh berlaku kepada remaja perempuan ketika mereka berada di dalam atau di luar rumah. Metodologi kajian menggunakan kaedah tinjauan yang melibatkan kajian kuantitatif dan dianalisis menggunakan perisian statistik SPSS 2.0. Objektif kajian adalah untuk meneroka sejauh mana risiko gangguan seksual berlaku kepada remaja perempuan 


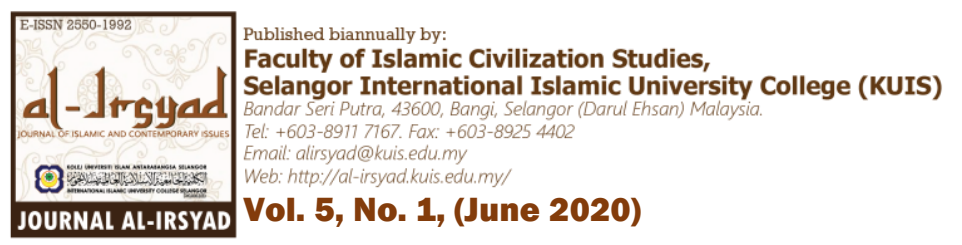

\begin{abstract}
sewaktu di dalam rumah. Seramai 84 orang remaja perempuan yang berusia sembilan hingga 15 tahun di negeri Selangor telah mendapat kebenaran daripada ibu bapa dan penjaga masing-masing untuk menjadi peserta kajian. Kajian mendapati seramai $7.14 \%$ remaja perempuan mengakui suka berpakaian seksi di rumah dan pernah menonton video pornografi bersama ahli keluarga terdekat seperti bapa, abang, bapa saudara serta datuk. Dapatan juga menunjukkan mereka mengalami gangguan seksual dalam kalangan ahli keluarga sekiranya mereka tidak menjaga adab-adab Islam disamping banyak terdedah dengan kemudahan teknologi maklumat yang tiada batasan. Dapatan juga menunjukkan wujudnya elemen yang tidak selamat kepada anak-anak remaja perempuan yang berada dalam rumah sekiranya mekanisme kesejahteraan keluarga tidak dipelihara dengan baik dan betul. Implikasi kajian ini mencadangkan pembangunan sebuah aplikasi mudah alih bagi mengenalpasti tanda-tanda awal gangguan seksual yang berlaku kepada remaja perempuan.
\end{abstract}

\title{
1. Pendahuluan
}

Keluarga adalah institusi yang paling selamat untuk melindungi anak-anak daripada bahaya dan gangguan. Allah SWT menganugerahkan ibu dan bapa sebagai pemimpin dan pelindung kepada ahli keluarga. Malah Islam menjadikan ayah sebagai wali yang bertanggungjawab kepada anak-anak perempuan dan imam yang memimpin ahli keluarga yang lain. Keluarga yang sihat merupakan tunggak penting dalam melahirkan individu dan komuniti sejahtera. Kesejahteraan individu secara psikologi, mental dan fizikal boleh membantu membina komuniti yang makmur dari segi sosial, ekonomi dan kesejahteraan ekologi manusia (Hasan, Yusoff \& Alavi 2012). Manakala Ulwan (2015) telah menggariskan tujuh aspek pendidikan yang dipertanggungjawabkan kepada setiap ibu bapa. Aspek tersebut adalah pendidikan iman, pendidikan akhlak, pendidikan jasmani, pendidikan mental, pendidikan psikologi serta pendidikan sosial. Ketujuh aspek pendidikan ini perlu diterapkan dalam jiwa anak-anak bagi membentuk anggota keluarga yang sejahtera dan selamat. Keluarga juga merupakan medan untuk mengembangkan potensi yang dimiliki seorang anak ke arah pengembangan keperibadian diri yang positif dan baik serta berperanan mewujudkan proses pendidikan generasi yang cerdas dan berakhlak mulia. Walau bagaimanapun, anak-anak masih terdedah dengan ancaman gangguan seksual, fizikal, mental atau emosi di dalam rumah sendiri. Golongan remaja perempuan adalah kumpulan yang mudah terdedah dengan risiko gangguan seksual kerana tahap usia dan pertumbuhan fizikal badan yang sedang berkembang. Menurut Mohd. Salleh (2020) tanda-tanda kematangan seorang remaja boleh dilihat daripada kematangan seksual dan kematangan kelenjar reproduksi. Di mana usia seorang remaja perempuan bermula antara usia 11-13 tahun dan berlanjutan sehingga berumur 17 tahun. Walau bagaimanapun, usia sebenarnya seorang remaja merujuk usia baligh dan mencapai tahap mukalaf dalam Islam di mana had usia paling minima adalah 9 tahun (Puteh, 2001). Ini selari dengan Akta 21 Akta Umur Dewasa 1971 (UUM, 2006) yang menetapkan usia dewasa ialah 18 tahun ke atas. Manakala usia bawah 18 tahun disebut sebagai kanak-kanak.

\section{Gangguan Seksual terhadap remaja}

Undang-undang telah melindungi remaja bawah umur daripada dieksploitasi oleh golongan dewasa termasuk eksploitasi daripada aspek seksualiti melalui Akta Kanak-Kanak 2001, Konvensyen Hak Kanak-Kanak 1989 dan Akta Kesalahan Seksual Kanak-Kanak 2017 (Abd. Wahab \& Mat Nor, 2018). Merujuk kepada Bab 1 Seksyen 17 Akta 611 Akta Kanak-Kanak 2001 (UUM, 2006) mendefinisikan gangguan atau penderaan seksual kanak-kanak sebagai mereka yang teraniaya dari segi seks jika dia mengambil bahagian, sama ada sebagai 


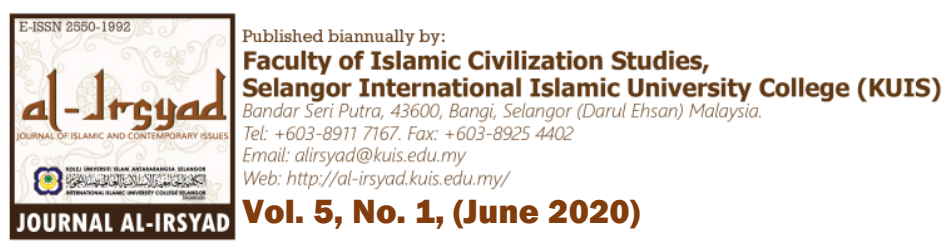

peserta atau pemerhati, dalam apa-apa aktiviti yang berunsur seks bagi apa-apa maksud atau eksploitasi seks oleh mana-mana orang bagi memuaskan nafsu seks orang itu atau orang lain. Penderaan seksual akan meninggalkan kesan yang mendalam kepada diri mangsa. Antaranya kanak-kanak akan mengalami trauma emosi seperti kemurungan, perubahan tingkah laku, trauma seksual juga mengalami kecederaan fizikal seperti lebam, pendarahan, kemerah-merahan dan ruam khususnya di bahagian alat sulit. Takrifan ini selari dengan kenyataan yang dikeluarkan dalam Report of the Consultation on Child Abuse Prevention oleh World Health Organization (WHO, 1999) yang mendefinisikan penderaan seksual kanak-kanak sebagai penglibatan kanakkanak dalam kegiatan seksual yang tidak difahaminya dengan baik, yang tidak dapat dipersetujuinya dengan arif, atau yang melanggar undang-undang atau kelaziman masyarakat. Penderaan seksual tersebut merangkumi perbuatan meraba-raba kemaluan, memperkosa, merogol dan menaikkan syahwat kanak-kanak dengan meminta secara tidak berpatutan, mendedahkan bahagian tubuh yang sulit atau menunjukkan bahan-bahan lucah. Kelakuan yang tidak melibatkan sentuhan seperti mengintai, mendedahkan bahagian tubuh yang sulit dan katakata lucah yang diucapkan kepada kanak-kanak juga merupakan penderaan seksual. Selain itu, mengeksploitasikan kanak-kanak untuk tujuan pornografi melalui internet dan menggunakan bahan tersebut untuk membolehkan seseorang kanak-kanak itu digunakan oleh orang lain sebagai pelacur juga merupakan suatu bentuk penganiayaan seksual. Lazimnya penderaan seksual terhadap kanak-kanak bertujuan memberi kepuasan seksual kepada orang yang melakukannya.

Menurut Zakaria et al. (2001), tiada definisi yang tepat untuk istilah gangguan seksual, namun begitu secara umumnya ia boleh digambarkan sebagai perilaku berbentuk seksual oleh seorang individu yang mempunyai kuasa jawatan atau kuasa peribadi kepada individu lain di bawah kekuasaannya. Oleh sebab itu, institusi keluarga perlu memainkan peranan bagi melindungi anak-anak daripada ancaman seksual dan gangguan fizikal (Mohd. Salleh et al. 2018). Permasalahan remaja yang terdedah dengan gangguan seksual sering dilaporkan oleh akhbar dan berita arus perdana. Mat Ruzki (2017) melaporkan untuk akhbar Berita Harian tentang seorang bapa dijangka didakwa di Mahkamah atas kesalahan Seksual Terhadap Kanak-kanak membabitkan sekurang-kurangnya 600 dakwaan atas kesalahan meliwat dan merogol anak perempuannya. Laporan oleh Meor Ahmad (2017) dalam Harian Metro, menyebut tentang seorang bapa yang mengaku bersalah merogol anak tirinya sehingga menimbulkan perasaan trauma mangsa untuk berhadapan dengan masyarakat. Begitu juga laporan BERNAMA (2019) berkaitan seorang bapa yang tergamak merogol, mencabul dan merakam gambar bogel anak tirinya.

Laporan Ngah, Mohamad \& Rosli (2017) dalam Berita Harian berkaitan perangkaan jenayah rogol dan penderaan seksual yang dikeluarkan oleh Polis diRaja Malaysia dan Kementerian Pembangunan Wanita, Keluarga dan Masyarakat. Menurut Ngah et al. (2017), kesalahan rogol adalah kategori paling tinggi bagi kes penderaan seksual kanak-kanak bagi tempoh tahun 2010 hingga Mei 2017, diikuti cabul, sumbang mahram dan luar tabii. Berdasarkan perangkaan Polis Diraja Malaysia (PDRM), sebanyak 13,272 kes rogol atau 59.7 peratus direkodkan bagi tempoh berkenaan, manakala cabul (6,014 kes atau 27.04 peratus), sumbang mahram (1,766 kes atau 8.07 peratus) dan luar tabii (1,152 kes atau 5.18 peratus). Begitu juga perangkaan yang dikeluarkan oleh Kementerian Pembangunan Wanita, Keluarga dan Masyarakat menunjukkan jumlah penderaan kanakkanak meningkat setiap tahun. Sebanyak 4,652 kes penderaan kanak-kanak direkodkan sepanjang tahun 2015 hingga tahun 2016. Daripada jumlah itu, penderaan fizikal mencatatkan kes paling tinggi iaitu 2,470 kes manakala 2,012 kes adalah penderaan seksual selain penderaan emosi sebanyak 170 kes.

Senario yang ditunjukkan dalam laporan akhbar dan statistik daripada Kementerian Pembangunan Wanita, Keluarga dan Masyarakat serta Polis Diraja Malaysia ini menunjukkan keadaan keselamatan rumah sebagai tempat berlindung anak-anak terutamanya anak-anak perempuan amat membimbangkan. Kajian yang dilakukan oleh Salleh (2018) menunjukkan kaum Melayu merupakan kaum yang tertinggi dalam masyarakat yang menyumbang kepada kes-kes sumbang mahram ini. Dasar kebajikan dan sosial kerajaan yang kurang memberi penekanan kepada pembelaan nasib kanak-kanak dari keluarga miskin atau keluarga yang porakperanda dan masyarakat yang terlalu mengongkong juga menyumbang kepada masalah ini. Kajian Salleh (2018) juga menunjukkan majoriti kes sumbang mahram yang dilaporkan adalah membabitkan masyarakat Melayu. Sebahagian besarnya adalah daripada kes yang membabitkan keluarga yang dikategorikan sebagai amat miskin, 


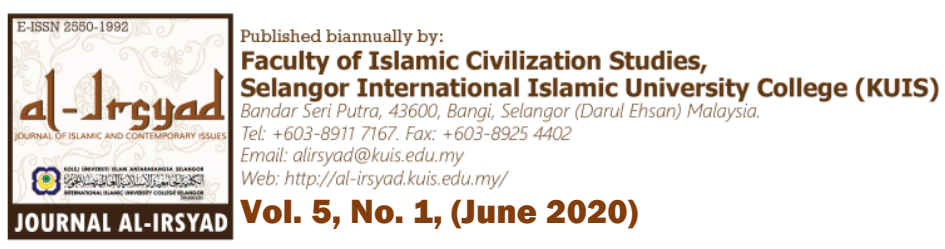

iaitu keluarga yang tidak berupaya untuk membela dan membesarkan anak-anak mereka dengan sempurna. Tanpa campur tangan kerajaan, anak-anak daripada keluarga ini, jika mereka perempuan, mudah menjadi mangsa sumbang mahram; sementara yang lelaki pula akan terlibat dengan kegiatan sosial lain seperti lumba haram atau jenayah.

Shazwani (2019) melaporkan sejumlah 1,291 kes penderaan seksual kanak-kanak dirujuk kepada pasukan SCAN (Pasukan penderaan dan pengabaian kanak-kanak yang disyaki) hospital sepanjang tahun 2018, di mana jumlah itu lebih satu pertiga daripada 3, 308 kes penderaan yang direkodkan. Turut dilaporkan lebih $70 \%$ kes penderaan seksual kanak-kanak adalah diganggu oleh pemangsa yang dikenali.

Hal ini menunjukkan keluarga bukan lagi tempat yang benar-benar selamat bagi remaja. Mereka berisiko untuk mendapat gangguan seksual bukan sahaja di luar rumah tetapi juga di dalam rumah. Ini menunjukkan kesejahteraan institusi keluarga yang berperanan memelihara kesejahteraan kanak-kanak semakin longgar fungsinya. Hal ini dapat dilihat daripada Laporan Indeks Kesejahteraan Keluarga Malaysia 2016 oleh Lembaga Pembangunan Penduduk dan Keluarga Negara (LPPKN 2017) yang menunjukkan kesejahteraan keluarga di Malaysia adalah masih pada tahap yang sederhana. Kajian yang dilaksanakan 10 tahun sekali itu mendedahkan pada tahun 2011 domain hubungan kekeluargaan, ekonomi keluarga, kesihatan keluarga, keselamatan keluarga, keluarga dan komuniti, keluarga dan agama/kerohanian serta perumahan dan persekitaran telah mencapai skor 7.55 (LPPKN 2011). Manakala Indeks Kesejahteraan Keluarga pada tahun 2016 menunjukkan domain keluarga dan teknologi komunikasi mencatatkan penurunan berbanding indeks pada tahun 2011 dengan catatan skor 7.33 (LPPKN 2016). Penurunan ini menunjukkan rekod kesejahteraan keluarga di Malaysia semakin merosot dan dibimbangi akan terus mencatatkan kemerosotan pada masa akan datang. Justeru, kajian ini berusaha untuk melihat sejauhmana remaja perempuan terdedah dengan risiko gangguan seksual sewaktu berada di dalam rumah.

\section{Metodologi Kajian}

Metodologi kajian ini menggunakan pendekatan kuantitatif dengan membangunkan instrumen soal selidik yang dianalisis menggunakan perisian statistik Statistical Product and Service Solutions (SPSS versi 20.0). Instrumen kajian dibangunkan berdasarkan kajian literatur, laporan Indeks Kesejahteraan Keluarga di Malaysia Malaysia 2016 dan hasil temubual bersama pegawai PDRM. Tujuan kajian adalah untuk meninjau sejauh mana gangguan seksual berlaku terhadap remaja perempuan di dalam rumah. Instrumen ini mengandungi lima (5) indikator keluarga sejahtera daripada gangguan seksual, di mana setiap satu indikator mempunyai lima item soal selidik. Indikator pertama ialah berkenaan dengan diri sendiri, indikator kedua tentang ibadat yang dilakukan, indikator ketiga tentang struktur rumah, indikator keempat berkaitan dengan keluarga manakala indikator kelima berkaitan dengan kesihatan. Instrumen kajian ini telah disahkan oleh 12 orang pakar yang terdiri daripada pegawai Lembaga Pembangunan Penduduk dan Keluarga Negara (LPPKN), Polis Diraja Malaysia (PDRM), Jabatan Kemajuan Islam Malaysia (JAKIM), Jabatan Kebajikan Malaysia (JKM), pegawai perubatan hospital dan guru sekolah. Kajian ini merupakan kajian rintis yang melibatkan seramai 84 orang remaja di Negeri Selangor bersetuju untuk menjadi peserta kajian. Surat kebenaran menjawab soal selidik telah diedarkan terlebih dahulu kepada ibu bapa dan penjaga. Hanya remaja yang mendapat kebenaran penjaga sahaja dibenarkan menjawab soal selidik ini. Pemilihan remaja ini adalah berdasarkan kepada status keluarga yang terdiri daripada golongan berada, sederhana dan kurang berkemampuan. Para remaja ini telah ditempatkan di sebuah dewan seminar khas dan diberi penerangan ringkas sebelum menjawab soalan. Sebanyak 84 set soal selidik diedarkan dan semua remaja telah menjawab dengan baik semua soal selidik tersebut. Pemilihan peserta kajian seramai 84 orang sebagai satu kajian rintis sebelum kajian sebenar dilaksanakan. Jumlah ini selari dengan Connelly (2008) dan Treece \& Treece (2005) yang menyarankan bilangan sampel untuk kajian rintis adalah $10 \%$ daripada sampel sebenar, di mana bilangan maksimum sampel yang ideal untuk kajian sosial kuantitatif adalah 500 orang (Sekaran, 2000), 10\% daripada 500 adalah 50 orang. 


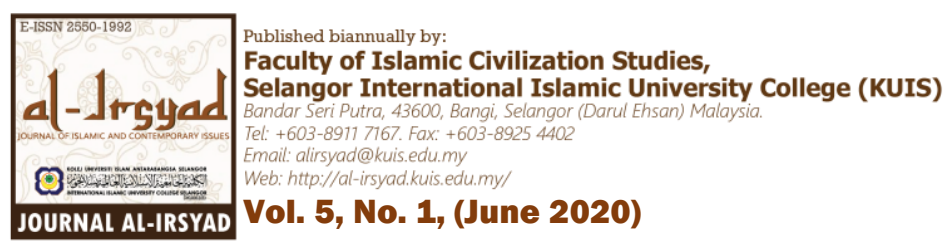

\section{Dapatan Kajian}

Seramai 84 peserta daripada remaja perempuan telah mengambil bahagian dalam kajian ini. 18 orang berusia $9-$ 10 tahun, 50 remaja berusia 11-12 tahun dan 16 remaja lagi berusia 13-15 tahun. Seramai 66 orang remaja tinggal di rumah teres, dua orang tinggal di rumah pangsa, 9 orang tinggal di banglo dan 7 orang lagi tinggal di rumah yang berbagai-bagai jenis. Seramai 78 orang remaja tinggal bersama ibu dan bapa masing-masing, mana kala tiga (3) daripadanya tinggal bersama ibu, dua (2) tinggal bersama bapa dan seorang tinggal bersama datuk dan nenek. Para peserta kajian diuji untuk menjawab soal selidik yang melibatkan lima indikator keluarga sejahtera daripada gangguan seksual yang berkaitan dengan diri sendiri, keluarga, rumah, ibadah dan kesihatan. Berdasarkan maklumbalas seperti di bawah dalam jadual 1 sehingga jadual 5, remaja perempuan berisiko untuk mengalami gangguan seksual di dalam rumah sekiranya mereka berpakaian seksi, menonton video pornografi dan suka melayari media sosial seperti begolive dan wechat, tinggal di dalam rumah yang sempit, tidak mempunyai kemudahan bilik tidur yang mencukupi, mempunyai ahli keluarga lelaki yang tidak bekerja atau pun bersikap terlalu romantik, mengalami sakit pada alat sulit, sering merasa loya, sakit ketika membuang air kecil, sakit perut dan berat badan bertambah. Kajian juga menunjukkan amal ibadat berperanan melindungi remaja perempuan daripada mudah terjebak dalam gangguan seksual di dalam rumah. Hasil dapatan ini dinyatakan dalam Jadual 1 sehingga Jadual 5 seperti di bawah.

Jadual 1. Maklumbalas peserta kajian berkaitan indikator diri

\begin{tabular}{|c|c|c|c|c|c|c|c|c|c|c|}
\hline \multirow{2}{*}{$\begin{array}{l}\text { Kod } \\
\text { Diri saya }\end{array}$} & \multirow[t]{2}{*}{ Indikator } & \multicolumn{7}{|c|}{ Kekerapan \& Peratus $(\mathrm{N}=84)$} & \multicolumn{2}{|c|}{ Min \& SP } \\
\hline & & SSTS & STS & TS & $\mathbf{K S}$ & $\mathbf{S}$ & SS & SSS & Min & SP \\
\hline B1.1 & Saya seorang yang pendiam & $\begin{array}{l}22 \\
(26.2)\end{array}$ & $\begin{array}{l}14 \\
(16.7)\end{array}$ & $\begin{array}{l}14 \\
(16.7)\end{array}$ & $\begin{array}{l}23 \\
(27.4)\end{array}$ & $\begin{array}{l}4 \\
(4.8)\end{array}$ & $\begin{array}{l}2 \\
(2.4)\end{array}$ & $\begin{array}{l}5 \\
(6.0)\end{array}$ & 3.00 & 1.69 \\
\hline B1.2 & $\begin{array}{l}\text { Saya suka menyendiri di dalam } \\
\text { bilik }\end{array}$ & $\begin{array}{l}32 \\
(38.1)\end{array}$ & $\begin{array}{l}5 \\
(6.0)\end{array}$ & $\begin{array}{l}12 \\
(14.3)\end{array}$ & $\begin{array}{l}12 \\
(14.3)\end{array}$ & $\begin{array}{l}3 \\
(3.6)\end{array}$ & $\begin{array}{l}9 \\
(10.7)\end{array}$ & $\begin{array}{l}11 \\
(13.1)\end{array}$ & 3.23 & 2.22 \\
\hline B1.3 & $\begin{array}{l}\text { Saya suka memakai baju seksi } \\
\text { dalam rumah }\end{array}$ & $\begin{array}{l}61 \\
(72.6)\end{array}$ & $\begin{array}{l}9 \\
(10.7)\end{array}$ & $\begin{array}{l}2 \\
(2.4)\end{array}$ & $\begin{array}{l}4 \\
(4.8)\end{array}$ & $\begin{array}{l}2 \\
(2.4)\end{array}$ & $\begin{array}{l}4 \\
(4.8)\end{array}$ & $\begin{array}{l}2 \\
(2.4)\end{array}$ & 1.77 & 1.58 \\
\hline B1.4 & Saya trauma dengan lelaki & $\begin{array}{l}48 \\
(57.1)\end{array}$ & $\begin{array}{l}8 \\
(9.5)\end{array}$ & $\begin{array}{l}7 \\
(8.3)\end{array}$ & $\begin{array}{l}13 \\
(15.5)\end{array}$ & $\begin{array}{l}4 \\
(4.8)\end{array}$ & $\begin{array}{l}1 \\
(1.2)\end{array}$ & $\begin{array}{l}3 \\
(3.6)\end{array}$ & 2.19 & 1.67 \\
\hline B1.5 & $\begin{array}{l}\text { Saya suka berinteraksi melalui } \\
\text { begolive / wechat }\end{array}$ & $\begin{array}{l}59 \\
(70.2)\end{array}$ & $\begin{array}{l}8 \\
(9.5)\end{array}$ & $\begin{array}{l}2 \\
(2.4)\end{array}$ & $\begin{array}{l}3 \\
(3.6)\end{array}$ & $\begin{array}{l}4 \\
(4.8)\end{array}$ & $\begin{array}{l}1 \\
(1.2)\end{array}$ & $\begin{array}{l}7 \\
(8.3)\end{array}$ & 2.00 & 1.90 \\
\hline B1.6 & $\begin{array}{l}\text { Saya suka menonton video } \\
\text { pornografi bersama keluarga }\end{array}$ & $\begin{array}{l}73 \\
(86.9)\end{array}$ & $\begin{array}{l}3 \\
(3.6)\end{array}$ & $\begin{array}{l}1 \\
(1.2)\end{array}$ & $\begin{array}{l}1 \\
(1.2)\end{array}$ & 0 & $\begin{array}{l}1 \\
(1.2)\end{array}$ & $\begin{array}{l}5 \\
(6.0)\end{array}$ & 1.51 & 1.54 \\
\hline
\end{tabular}

Jadual 1 menunjukkan indikator diri yang mengukur sikap pendiam, suka menyendiri, suka memakai baju seksi, trauma dengan lelaki, suka berinteraksi melalui wechat dan begolive serta menonton video porno bersama keluarga. Data menunjukkan remaja perempuan berisiko mendapat gangguan seksual apabila 6 daripada 84 (7.14\%) remaja suka berpakaian seksi dalam rumah dan suka menonton video pornografi bersama ahli keluarga. Malah 8 daripada 84 (9.52\%) remaja ini suka berinteraksi melalui begolive dan wechat, iaitu satu aplikasi jaringan meluas yang membuka ruang perkenalan antara penduduk maya dalam internet dengan begitu mudah. Kajian ini menunjukkan remaja perempuan berisiko mendapat gangguan seksual di dalam rumah sekiranya mereka berpakaian seksi, menonton video pornografi dan suka melayari media sosial seperti begolive dan wechat. Dapatan ini selari dengan petunjuk dalam Indeks Kesejahteraan Keluarga Malaysia 2016 (LPPKN, 2017) yang menunjukkan kawalan keluarga terhadap penggunaan teknologi komunikasi anak-anak seperti SMS, whatapps, wechat berada pada tahap sederhana rendah iaitu skor min 5.23 berbanding skor penuh adalah 10.0.

Jadual 2. Maklumbalas peserta kajian berkaitan indikator ibadat

\begin{tabular}{|c|c|c|c|c|c|c|c|c|c|c|}
\hline \multicolumn{2}{|c|}{ Ibadat saya } & \multirow{2}{*}{$\begin{array}{l}\text { SSTS } \\
68 \\
(81.0)\end{array}$} & \multirow{2}{*}{$\begin{array}{l}\text { STS } \\
8 \\
(9.5)\end{array}$} & \multirow{2}{*}{$\begin{array}{l}\text { TS } \\
4 \\
(4.8)\end{array}$} & \multirow{2}{*}{$\begin{array}{l}\mathbf{K S} \\
1 \\
(1.2)\end{array}$} & \multirow{2}{*}{$\begin{array}{l}\mathbf{S} \\
1 \\
(1.2)\end{array}$} & \multirow{2}{*}{$\begin{array}{l}\text { SS } \\
1 \\
(1.2)\end{array}$} & \multirow{2}{*}{$\begin{array}{l}\text { SSS } \\
1 \\
(1.2)\end{array}$} & \multirow{2}{*}{$\begin{array}{l}\text { Min } \\
1.40\end{array}$} & \multirow{2}{*}{$\frac{\text { SP }}{1.08}$} \\
\hline B2.1 & $\begin{array}{l}\text { Saya tidak suka menunaikan } \\
\text { solat }\end{array}$ & & & & & & & & & \\
\hline B 2.2 & $\begin{array}{l}\text { Saya tidak pernah membaca al- } \\
\text { Quran }\end{array}$ & $\begin{array}{l}80 \\
(95.2)\end{array}$ & 0 & $\begin{array}{l}1 \\
(1.2)\end{array}$ & 0 & $\begin{array}{l}1 \\
(1.2)\end{array}$ & 0 & $\begin{array}{l}2 \\
(2.4)\end{array}$ & 1.21 & 1.03 \\
\hline B2.3 & Saya tidak pernah berdoa & 79 & 1 & 1 & 0 & 1 & 1 & 1 & 1.21 & 0.97 \\
\hline
\end{tabular}




\begin{tabular}{|c|c|c|c|c|c|c|c|c|c|c|c|}
\hline \multicolumn{2}{|c|}{ 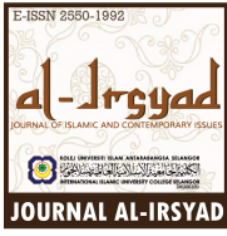 } & \multicolumn{5}{|c|}{$\begin{array}{l}\text { Published biannually by: } \\
\text { Faculty of Islamic Civilization Studies, } \\
\text { Selangor International Islamic University College (KUIS) } \\
\text { Bandar Seri Putra, } 43600, \text { Bangi, Selangor (Darul Ehsan) Malaysia. } \\
\text { Tel: +603-8917 } 7167 \text {. Fax: +603-8925 } 4402 \\
\text { Email: alirsyad@kuisedu.my } \\
\text { Web: http://al-irsyad.kuis.edumy/ } \\
\text { Vol. 5, No. 1, (June 2020) }\end{array}$} & \multirow[b]{2}{*}{$(1.2)$} & \multirow[b]{2}{*}{$(1.2)$} & \multirow[b]{2}{*}{$(1.2)$} & \multirow[b]{3}{*}{1.14} & \multirow[b]{3}{*}{0.75} \\
\hline \multirow[b]{2}{*}{ B2.4 } & \multicolumn{2}{|c|}{ kepada Allah } & (94.) & $(1.2)$ & $(1.2)$ & & & & & & \\
\hline & $\begin{array}{l}\text { Saya tida } \\
\text { telekung }\end{array}$ & $\begin{array}{l}\text { k mempunyai } \\
\text { sembahyang }\end{array}$ & $\begin{array}{l}80 \\
(95.2)\end{array}$ & 0 & $\begin{array}{l}3 \\
(3.6)\end{array}$ & 0 & 0 & 0 & $\begin{array}{l}1 \\
(1.2)\end{array}$ & & \\
\hline B2.5 & Saya tida & $\mathrm{k}$ memakai tudung & $\begin{array}{l}73 \\
(86.9)\end{array}$ & $\begin{array}{l}3 \\
(3.6)\end{array}$ & $\begin{array}{l}2 \\
(2.4)\end{array}$ & $\begin{array}{l}3 \\
(3.6)\end{array}$ & 0 & 0 & $\begin{array}{l}3 \\
(3.6)\end{array}$ & 1.40 & 1.26 \\
\hline B2.6 & Saya tida & $\mathrm{k}$ suka kelas agama & $\begin{array}{l}75 \\
(89.3)\end{array}$ & $\begin{array}{l}5 \\
(6.0)\end{array}$ & $\begin{array}{l}1 \\
(1.2)\end{array}$ & $\begin{array}{l}2 \\
(2.4)\end{array}$ & 0 & 0 & $\begin{array}{l}1 \\
(1.2)\end{array}$ & 1.22 & 0.84 \\
\hline
\end{tabular}

Jadual 2 menunjukkan indikator ibadat yang mengukur ibadat solat, bacaan al-Quran, amalan berdoa, pemakaian tudung dan kehadiran ke kelas agama. Kajian menunjukkan 95\% remaja mempunyai tahap kesedaran yang tinggi terhadap ibadat. Walau bagaimanapun tiga (3) daripada 84 (3.57\%) remaja tidak suka menunaikan solat, membaca al-Quran, berdoa kepada Allah SWT, tidak suka memakai tudung dan menghadiri kelas agama. Ini menunjukkan amal ibadat berperanan melindungi remaja perempuan daripada mudah terjebak dalam gangguan seksual di dalam rumah. Dapatan ini selari dengan kajian Mohamad dan Ishak (2014) yang mendapati pegangan agama yang longgar menyumbang kepada gejala seksual dalam kalangan pelajar di Negeri Sabah.

Jadual 3. Maklumbalas peserta kajian berkaitan indikator rumah

\begin{tabular}{|c|c|c|c|c|c|c|c|c|c|c|}
\hline \multicolumn{2}{|c|}{ Rumah saya } & SSTS & STS & TS & $\mathbf{K S}$ & $\mathbf{S}$ & SS & SSS & Min & SP \\
\hline B3.1 & Rumah saya tiada bilik tidur & $\begin{array}{l}80 \\
(95.2)\end{array}$ & 0 & $\begin{array}{l}2 \\
(2.4)\end{array}$ & 0 & 0 & 0 & $\begin{array}{l}2 \\
(2.4)\end{array}$ & 1.23 & 1.29 \\
\hline B3.2 & $\begin{array}{l}\text { Rumah saya ada satu bilik air } \\
\text { sahaja }\end{array}$ & $\begin{array}{l}77 \\
(91.7)\end{array}$ & 0 & $\begin{array}{l}1 \\
(1.2)\end{array}$ & $\begin{array}{l}1 \\
(1.2)\end{array}$ & 0 & 0 & $\begin{array}{l}5 \\
(6.0)\end{array}$ & 1.41 & 1.47 \\
\hline B3.3 & Rumah saya sempit & $\begin{array}{l}71 \\
(84.5)\end{array}$ & $\begin{array}{l}5 \\
(6.0)\end{array}$ & $\begin{array}{l}1 \\
(1.2)\end{array}$ & $\begin{array}{l}1 \\
(1.2)\end{array}$ & $\begin{array}{l}3 \\
(3.6)\end{array}$ & $\begin{array}{l}1 \\
(1.2)\end{array}$ & $\begin{array}{l}2 \\
(2.4)\end{array}$ & 1.46 & 1.32 \\
\hline B3.4 & Rumah saya jauh daripada jiran & $\begin{array}{l}77 \\
(91.7)\end{array}$ & $\begin{array}{l}4 \\
(4.8)\end{array}$ & 0 & 0 & $\begin{array}{l}2 \\
(2.4)\end{array}$ & 0 & $\begin{array}{l}1 \\
(1.2)\end{array}$ & 1.21 & 0.91 \\
\hline B3.5 & $\begin{array}{l}\text { Rumah saya ada wifi / internet / } \\
\text { astro / parabola }\end{array}$ & $\begin{array}{l}11 \\
(13.1)\end{array}$ & $\begin{array}{l}4 \\
(4.8)\end{array}$ & $\begin{array}{l}1 \\
(1.2)\end{array}$ & $\begin{array}{l}5 \\
(6.0)\end{array}$ & $\begin{array}{l}7 \\
(8.3)\end{array}$ & $\begin{array}{l}8 \\
(9.5)\end{array}$ & $\begin{array}{l}48 \\
(57.1)\end{array}$ & 5.48 & 2.20 \\
\hline B3.6 & $\begin{array}{l}\text { Saya berasa tidak selamat berada } \\
\text { di dalam rumah }\end{array}$ & $\begin{array}{l}58 \\
(69.0)\end{array}$ & $\begin{array}{l}15 \\
(17.9)\end{array}$ & $\begin{array}{l}2 \\
(2.4)\end{array}$ & $\begin{array}{l}4 \\
(4.8)\end{array}$ & $\begin{array}{l}2 \\
(2.4)\end{array}$ & $\begin{array}{l}2 \\
(2.4)\end{array}$ & $\begin{array}{l}1 \\
(1.2)\end{array}$ & 1.65 & 1.30 \\
\hline
\end{tabular}

Jadual 3 menunjukkan indikator rumah yang mengukur jumlah bilik tidur, jumlah bilik air, keluasan rumah, jarak rumah, kemudahan internet dan perasaan selamat. Kajian menunjukkan 95\% remaja berpuas hati dengan keadaan rumah masing-masing. Walau bagaimanapun, terdapat dua orang remaja (2.38\%) yang mendakwa tidak mempunyai bilik tidur, 5 orang remaja $(5.95 \%)$ mempunyai hanya satu bilik air, 6 orang remaja (7.14\%) mengakui rumah mereka sempit, tiga orang remaja (3.57\%) mengakui rumah mereka jauh dari kejiranan, 20 orang remaja (23.8\%) mempunyai kemudahan internet seperti astro, parabola dan wifi serta 5 orang remaja $(5.95 \%)$ merasai tidak selamat berada dalam rumah. Ini menunjukkan remaja perempuan lebih berisiko sekiranya tinggal di dalam rumah yang sempit dan tidak mempunyai kemudahan bilik tidur yang mencukupi. Kajian ini selari dengan petunjuk daripada Indeks Kesejahteraan Keluarga Malaysia 2016 (LPPKN, 2017) yang menunjukkan skor sederhana bagi domain perumahan dan persekitaran iaitu skor min 6.24 berbanding skor penuh adalah 10 .

Jadual 4. Maklumbalas peserta kajian berkaitan indikator keluarga

\begin{tabular}{|c|c|c|c|c|c|c|c|c|c|c|}
\hline \multicolumn{2}{|c|}{ Keluarga saya } & SSTS & STS & TS & $\mathbf{K S}$ & $\mathbf{S}$ & SS & SSS & Min & SP1 \\
\hline B4.1 & $\begin{array}{l}\text { Ibu saya keluar bekerja pada } \\
\text { waktu malam }\end{array}$ & $\begin{array}{l}69 \\
(82.1)\end{array}$ & $\begin{array}{l}4 \\
(4.8)\end{array}$ & $\begin{array}{l}3 \\
(3.6)\end{array}$ & $\begin{array}{l}2 \\
(2.4)\end{array}$ & $\begin{array}{l}1 \\
(1.2)\end{array}$ & 0 & $\begin{array}{l}5 \\
(6.0)\end{array}$ & 1.59 & 1.55 \\
\hline B4.2 & Ayah saya tidak bekerja & $\begin{array}{l}76 \\
(90.5)\end{array}$ & 0 & $\begin{array}{l}2 \\
(2.4)\end{array}$ & $\begin{array}{l}1 \\
(1.2)\end{array}$ & $\begin{array}{l}2 \\
(2.4)\end{array}$ & $\begin{array}{l}1 \\
(1.2)\end{array}$ & $\begin{array}{l}2 \\
(2.4)\end{array}$ & 1.38 & 1.27 \\
\hline B4.3 & $\begin{array}{l}\text { Saya tinggal bersama datuk } \\
\text { yang tidak bekerja }\end{array}$ & $\begin{array}{l}72 \\
(85.7)\end{array}$ & $\begin{array}{l}4 \\
(4.8)\end{array}$ & $\begin{array}{l}1 \\
(1.2)\end{array}$ & 0 & $\begin{array}{l}2 \\
(2.4)\end{array}$ & 0 & $\begin{array}{l}5 \\
(6.0)\end{array}$ & 1.52 & 1.54 \\
\hline B4.4 & $\begin{array}{l}\text { Ayah sangat romantik dengan } \\
\text { saya }\end{array}$ & $\begin{array}{l}65 \\
(77.4)\end{array}$ & $\begin{array}{l}7 \\
(8.3)\end{array}$ & $\begin{array}{l}2 \\
(2.4)\end{array}$ & $\begin{array}{l}5 \\
(6.0)\end{array}$ & $\begin{array}{l}2 \\
(2.4)\end{array}$ & 0 & $\begin{array}{l}3 \\
(3.6)\end{array}$ & 1.62 & 1.42 \\
\hline B 4.5 & $\begin{array}{l}\text { Datuk dan abang juga romantik } \\
\text { dengan saya }\end{array}$ & $\begin{array}{l}72 \\
(85.7)\end{array}$ & $\begin{array}{l}5 \\
(6.0)\end{array}$ & $\begin{array}{l}2 \\
(2.4)\end{array}$ & $\begin{array}{l}2 \\
(2.4)\end{array}$ & $\begin{array}{l}1 \\
(1.2)\end{array}$ & 0 & $\begin{array}{l}2 \\
(2.4)\end{array}$ & 1.37 & 1.13 \\
\hline
\end{tabular}




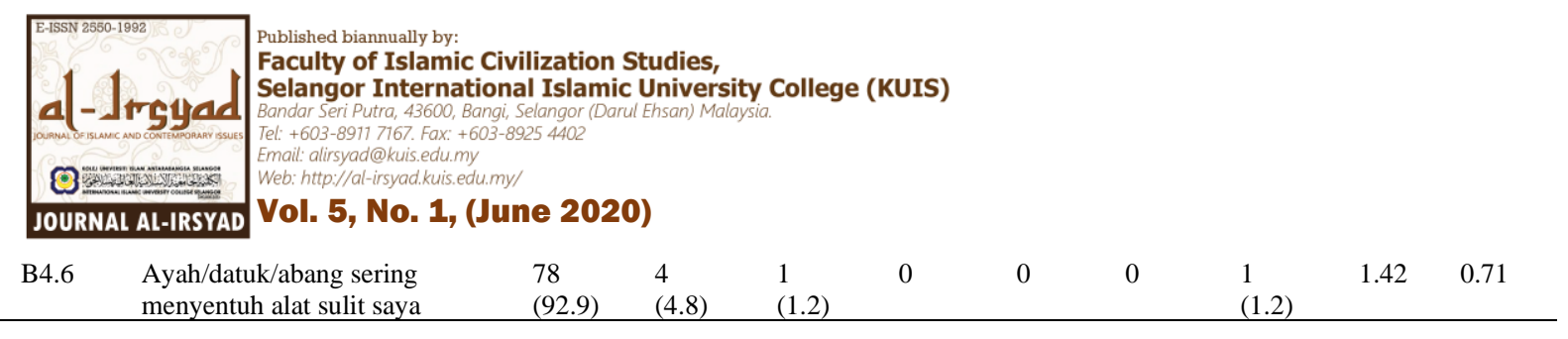

Jadual 4 menunjukkan indikator keluarga yang mengukur pekerjaan ibu, ayah dan datuk serta sikap romantik ayah dan ahli keluarga lelaki. Kajian menunjukkan pekerjaan dan sikap ahli keluarga tidak menunjukkan kepada risiko gangguan seksual terhadap $90 \%$ anak-anak remaja perempuan. Namun begitu, risiko ini masih terdapat pada $10 \%$ remaja perempuan, di mana 6 orang remaja $(7.14 \%)$ yang mempunyai ibu yang bekerja pada sebelah malam, 5 orang remaja (5.95\%) mempunyai ayah yang tidak bekerja, 7 orang remaja $(8.33 \%)$ tinggal bersama datuk yang tidak bekerja, 5 orang remaja $(5.95 \%)$ mengakui ayah menunjukkan sikap romantis terhadap mereka, tiga (3) orang remaja (3.57\%) mengakui datuk dan abang menunjukkan sikap romantis dan seorang $(1.19 \%)$ mengakui sama ada ayah, datuk atau abang sering menyentuh alat sulit. Ini menggambarkan remaja perempuan berisiko mendapat gangguan seksual di dalam rumah yang mempunyai ahli keluarga lelaki yang tidak bekerja atau pun bersikap terlalu romantis. Dapatan ini selari dengan kajian Abd. Majid, Azman \& Mohd. Yani (2019) yang mendapati kesibukan ibubapa merupakan antara faktor yang menyumbang kepada remaja terjebak dalam kes hamil tanpa nikah. Kesibukan ibubapa yang serius menjurus kepada pengabaian perhatian dan kasih sayang terhadap anak-anak. Begitu juga dapatan daripada temubual bersama mangsa gangguan seksual yang mengesahkan remaja perempuan berisiko mendapat gangguan seksual sekiranya terdapat ahli keluarga lelaki yang tidak bekerja tinggal bersama (Zaim \& Mohd. Salleh 22 Mei 2019).

Jadual 5. Maklumbalas peserta kajian berkaitan indikator kesihatan

\begin{tabular}{|c|c|c|c|c|c|c|c|c|c|c|}
\hline \multicolumn{2}{|c|}{ Kesihatan saya } & SSTS & STS & TS & KS & $\mathbf{S}$ & SS & SSS & Min & SP \\
\hline B5.1 & $\begin{array}{l}\text { Saya sering sakit apabila } \\
\text { membuang air kecil }\end{array}$ & $\begin{array}{l}72 \\
(85.7)\end{array}$ & $\begin{array}{l}3 \\
(3.6)\end{array}$ & $\begin{array}{l}3 \\
(3.6)\end{array}$ & $\begin{array}{l}4 \\
(4.8)\end{array}$ & $\begin{array}{l}1 \\
(1.2)\end{array}$ & 0 & $\begin{array}{l}1 \\
(1.2)\end{array}$ & 1.37 & 1.05 \\
\hline B5.2 & $\begin{array}{l}\text { Saya sering merasa loya dan sakit } \\
\text { perut }\end{array}$ & $\begin{array}{l}52 \\
(61.9)\end{array}$ & $\begin{array}{l}9 \\
(10.0)\end{array}$ & $\begin{array}{l}12 \\
(14.3)\end{array}$ & $\begin{array}{l}6 \\
(7.1)\end{array}$ & 0 & $\begin{array}{l}1 \\
(1.2)\end{array}$ & $\begin{array}{l}4 \\
(4.8)\end{array}$ & 1.95 & 1.57 \\
\hline B5.3 & $\begin{array}{l}\text { Saya merasa sakit dibahagian alat } \\
\text { sulit }\end{array}$ & $\begin{array}{l}63 \\
(75.0)\end{array}$ & $\begin{array}{l}11 \\
(13.1)\end{array}$ & $\begin{array}{l}2 \\
(2.4)\end{array}$ & $\begin{array}{l}4 \\
(4.8)\end{array}$ & $\begin{array}{l}2 \\
(2.4)\end{array}$ & 0 & $\begin{array}{l}2 \\
(2.4)\end{array}$ & 1.55 & 1.26 \\
\hline B5.4 & Saya tiada selera untuk makan & $\begin{array}{l}59 \\
(70.2)\end{array}$ & $\begin{array}{l}9 \\
(10.7)\end{array}$ & $\begin{array}{l}7 \\
(8.30\end{array}$ & $\begin{array}{l}4 \\
(4.8)\end{array}$ & 0 & $\begin{array}{l}3 \\
(3.6)\end{array}$ & $\begin{array}{l}2 \\
(2.4)\end{array}$ & 1.73 & 1.45 \\
\hline B5.5 & Berat badan saya bertambah & $\begin{array}{l}33 \\
(39.3)\end{array}$ & $\begin{array}{l}13 \\
(15.5)\end{array}$ & $\begin{array}{l}7 \\
(8.3)\end{array}$ & $\begin{array}{l}9 \\
(10.7)\end{array}$ & $\begin{array}{l}3 \\
(3.6)\end{array}$ & $\begin{array}{l}7 \\
(8.3)\end{array}$ & $\begin{array}{l}12 \\
(14.3)\end{array}$ & 3.05 & 2.25 \\
\hline B5.6 & $\begin{array}{l}\text { Saya sering rungsing dan sakit } \\
\text { kepala }\end{array}$ & $\begin{array}{l}51 \\
(60.7)\end{array}$ & $\begin{array}{l}7 \\
(8.3)\end{array}$ & $\begin{array}{l}6 \\
(7.1)\end{array}$ & $\begin{array}{l}8 \\
(9.5) \\
\end{array}$ & $\begin{array}{l}4 \\
(4.8)\end{array}$ & $\begin{array}{l}3 \\
(3.6)\end{array}$ & $\begin{array}{l}5 \\
(6.0) \\
\end{array}$ & 2.23 & 1.88 \\
\hline
\end{tabular}

Jadual 5 menunjukkan indikator kesihatan yang mengukur masalah sewaktu membuang air kecil, masalah perut, alat sulit, selera makan, berat badan dan masalah sakit kepala. Kajian menunjukkan $96 \%$ remaja mempunyai tahap kesihatan yang selamat dan tidak berisiko mendapat gangguan seksual. Manakala dua (2) orang remaja $(2.38 \%)$ sering merasa sakit ketika membuang air kecil, 5 orang $(5.95 \%)$ sering merasa loya dan sakit perut, 4 orang $(4.76 \%)$ sakit pada alat sulit, 5 orang $(5.95 \%)$ tiada selera makan, 22 orang remaja $(26.19 \%)$ mengalami masalah berat badan yang bertambah dan 12 orang remaja (14.29\%) mengalami runsing dan sakit kepala. Ini menunjukkan remaja perempuan berisiko mendapat gangguan seksual di dalam rumah sekiranya mengalami sakit pada alat sulit, sering merasa loya, sakit ketika membuang air kecil, sakit perut dan berat badan bertambah. Dapatan ini selari dengan temubual yang dilakukan bersama pakar psikiatris kanak-kanak yang mengendalikan kes penderaan seksual terhadap kanak-kanak daripada Polis Diraja Malaysia (Zaim \& Mohd. Salleh, 23 Julai 2019) yang mengakui mangsa akan mengalami sakit ketika membuang air kecil.

\section{Kesimpulan}

Secara keseluruhannya, kajian ini dapat mengenalpasti tahap kesejahteraan anak-anak remaja perempuan sewaktu berada dalam rumah dan bersama dengan ahli keluarga mereka sendiri. Kajian mendapati risiko gangguan seksual di dalam rumah kepada remaja dapat dibahagikan kepada sikap kendiri remaja, amalan keagamaan, suasana persekitaran dalam rumah, sikap keluarga dan tahap kesihatan remaja. Walaupun peratus anak-anak remaja perempuan berada pada tahap yang selamat dan sejahtera, namun begitu terdapat juga remaja 


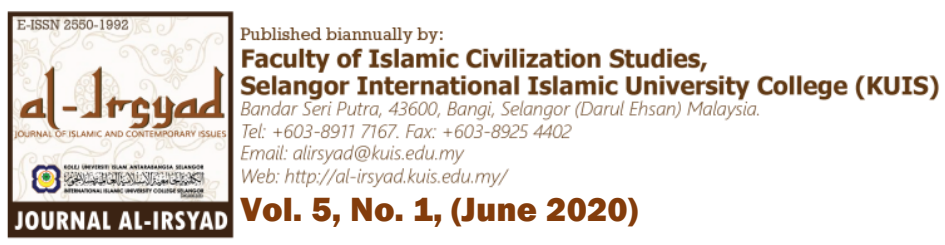

yang mempunyai risiko mendapat gangguan seksual sama ada daripada ayah sendiri, atau keluarga terdekat yang lain seperti abang dan datuk. Kajian menegaskan bahawa remaja perempuan berisiko mengalami gangguan seksual dalam kalangan ahli keluarga sekiranya mereka tidak menjaga adab-adab Islam dan banyak terdedah dengan kemudahan teknologi maklumat yang tiada batasan. Dapatan kajian ini penting untuk memberi kesedaran kepada ibu bapa dan ahli keluarga agar sentiasa memelihara adab-adab Islam sewaktu berada dalam rumah. Implikasi kepada dapatan ini, kajian mencadangkan agar membangunkan satu aplikasi mudah alih bagi mendapatkan maklumat dan data yang lebih terperinci tentang tanda-tanda awal gangguan seksual yang berlaku kepada remaja perempuan. Justeru, kesejahteraan anak-anak remaja perempuan sewaktu berada di rumah dapat dikenalpasti dan terjamin.

\section{Penghargaan}

Penghargaan diberikan kepada Kolej Universiti Islam Antarabangsa Selangor (KUIS) dan Geran Pembangunan dan Penyelidikan Sains, Tekonologi dan Invovasi (GPPSTI), Negeri Selangor (KUIS/GPPSTI/2017/001).

\section{Rujukan}

Abd. Majid, M., Azman, N. Z., \& Mohd Yani, N. I. (2019). Faktor Penglibatan Remaja dalam Salah Laku Seksual: Kajian Terhadap Remaja Hamil Luar Nikah di Pusat Pemulihan Akhlak Negeri Selangor. alIrsyad: Journal of Islamic and Contemporary Issues, 4(2), 94-109. Retrieved from http://alirsyad.kuis.edu.my/index.php/alirsyad/article/view/59

Abd. Wahab, N. \& Mat Nor, M. F. (2018). Akta Kesalahan-Kesalahan Seksual Terhadap Kanak-Kanak 2017: Penambahbaikan Perundangan Berkaitan Jenayah Seksual Terhadap Kanak-kanak di Malaysia. Journal of Muwafaqat. Vol. 1, No. 1, 2018, pp. 37-55.

Akta 611 Akta Kanak-Kanak 2001 (UUM). Pindaan 2006, Bab 1. Seksyen 17 (MY). Diambil semula daripada https://www.kpwkm.gov.my/kpwkm/ uploads/files/ Dokumen/Akta/Akta\%20Kanak-Kanak\%202001.pdf

Akta 21 Akta Umur Dewasa 1971 (UUM). Pindaan 2006, Seksyen 2 (MY). Diambil daripada http://www.agc.gov.my/agcportal/uploads/files/Publications/LOM/MY/Akta\%2021.pdf.

BERNAMA (11 Okt 2019). Bapa durjana didakwa rogol, cabul dan rakam gambar bogel anak tiri. Sinar Harian. Diambil daripada https://www.sinarharian.com.my/article/51558/KHAS/Isu/Bapa-durjanadidakwa-rogol-cabul-dan-rakam-gambar-bogel-anak-tiri.

Hasan, A., Yusoff, F. \& Alavi, K. (2012). Keluarga sihat melahirkan keluarga sejahtera. Satu ulasan. Malaysia Journal of Society and Space 8, Issue 5 (51 - 63).

Jailani, M. S. (2014). Teori pendidikan keluarga dan tangungjawab orang tua dalam pendidikan anak usia dini. Jurnal Pendidikan Islam. Vol. 8, No 2, 245-260.

Lembaga Penduduk dan Pembangunan Keluarga Negara (LPPKN). (2013). Laporan Indeks Kesejahteraan Keluarga di Malaysia 2011. Diambil semula daripada https://www.lppkn.gov.my/index.php/2014-04-2306-10-37/indeks-kesejahteraan-keluarga/29-laporan-kajian-indeks-kesejahteraan-keluarga-malaysia2011/file.

Lembaga Penduduk dan Pembangunan Keluarga Negara (LPPKN). (2017). Laporan Indeks Kesejahteraan Keluarga di Malaysia 2016. Diambil semula daripada http://online.fliphtml5.com/lgqm/bzlm/\#p=14.

Mat Ruzki, R. (8 Ogos 2017). Bapa berdepan 600 dakwaan liwat, rogol anak. Berita Harian. Diambil semula daripada https://www.bharian.com.my/berita/kes/2017/08/310178/bapa-berdepan-600-dakwaan-liwatrogol-anak.

Meor Ahmad, M. R. (15 Jan 2018). Ada isteri, tapi pilih rogol anak tiri. Harian Metro. Diambil daripada https://www.hmetro.com.my/mutakhir/2018/01/303792/ada-isteri-tapi-pilih-rogol-anak-tiri.

Mohamad, M. F. \& Ishak, M. Z. (2014). Gejala hubungan seks dalam kalangan pelajar: Satu Kajian Kes. Proseding Seminar Kebangsaan Intergriti Keluarga 2014. (hal. 1-10). Fakulti Psikologi dan Pendidikan, Universiti Malaysia Sabah (UMS). Diambil daripada https://www.ums.edu.my/fpp/ images/ download/ proseding skik2014/Mohamad_Faizal.pdf.

Mohd Salleh, N., Zaim, N. H., Rashed, Z. N., Haridi, N. M., Rahman, K. A. A. \& Misran, N. (2018). Statistik kes penderaan kanak-kanak di Malaysia: Satu analisis. International Journal for Studies on Children, Women, Elderly and Disabled, Vol. 5, (Oct.):17-24.

Mohd. Salleh, N. (2020). Panduan Hidup Berkeluarga. Bandar Baru Bangi: Abad Senergy. 


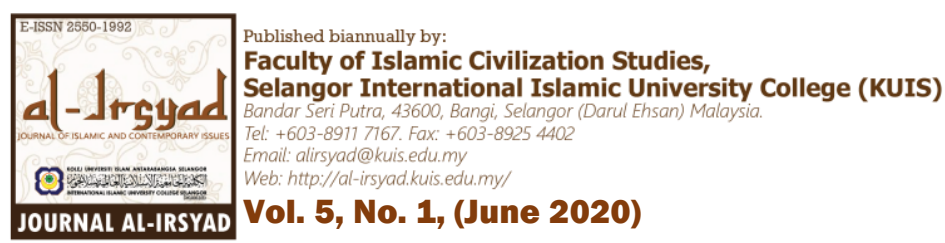

Ngah, N. Mohamad, H. F. \& Rosli, F. A. (27 Julai 2017). 13,272 kes rogol kanak-kanak dilaporkan. Berita Harian. Diambil daripada https://www.bharian.com.my/berita/nasional/2017/07/306192/13272-kes-rogolkanak-kanak-dilaporkan.

Puteh, A. (2001). Perkembangan dan pembentukan remaja menurut perspektif Islam. Kajian Malaysia. Jld XIX. No. 2. pp. 79-101.

Salleh, S. (16 Okt 2018). Sumbang Mahram Suatu Perbincangan. Portal Jabatan Agama Islam Selangor. Diambil daripada https://www.jais.gov.my/v2/page.php?id=450\&k=sumbang\%20mahram.

Shazwani, F. (22 April 2019). 1,291 kes penderaan seksual kanak-kanak. Sinar Harian. Diambil semula daripada https://www.sinarharian.com.my/article/24817/BERITA/Nasional/1291-kes-penderaan-seksualkanak-kanak.

Ulwan, Abdullah Nasih. (2015). Pendidikan anak-anak. Kuala Lumpur: JAKIM.

World Health Organization (WHO). (1999). Report of the Consultation on Child Abuse Prevention. Diambil daripada file:///C:/Users/Norsaleha/Downloads/WHO_HSC_PVI_99.1.pdf.

World Health Organization (WHO). (2017). Responding to children and adolescents who have been sexually abused. Diambil daripada file:///C:/Users/Norsaleha/Downloads/9789241550147-eng.pdf.

Zakaria, I., Mohd., H., Malik, A. \& Malani, A. (2001). Gangguan seksual di tempat kerja definisi, kesan dan langkah mengatasinya. Jelapang, 2 (2). pp. 1-12. 